\title{
Skin microvascular circulation is not affected by diabetes duration in young patients with non-complicated type 1 diabetes mellitus
}

Mikrokrążenie skórne nie zależy od czasu trwania choroby u młodych pacjentów z niepowikłaną cukrzycą typu 1

\author{
Melanie Wielicka¹, Jolanta Neubauer-Geryk², Agnieszka Brandt-Varma3, Małgorzata Myśliwiec³, \\ Leszek Bieniaszewski² \\ ${ }^{1}$ Medical University of Gdansk, Gdansk, Poland \\ ${ }^{2}$ Clinical Physiology Unit, Medical Simulation Centre, Medical University of Gdansk, Gdansk, Poland \\ ${ }^{3}$ Department of Pediatrics, Diabetology and Endocrinology, Medical University of Gdansk, Gdansk, Poland
}

This study was supported by the State Committee for Scientific Research ST-120 and ST 02-0559/07/136 (Medical University of Gdańsk, Poland).

\begin{abstract}
Introduction: Skin microcirculation is recognized as an appropriate model to use when investigating the relationship between cardiovascular risk factors and microvascular function. It is currently a matter of debate whether studies on skin microcirculation in young type 1 diabetic patients without existing microangiopathy may be helpful in identifying subjects with impaired endothelial function. Aim of the study: To evaluate the potential changes in skin microcirculation of patients up age of 18 years using capillaroscopy, post reactive hyperaemia $(\mathrm{PORH})$ and venous occlusion (VO) tests, and to establish the relationship between those changes and disease duration and metabolic control in patients with type 1 diabetes.

Material and methods: Study group consisted of 112 pediatric patients aged 8.4-18.0 years, with a median age of 14.95 years. The median diabetes duration and age at onset were 5 years and 9.6 years, respectively. The median $\mathrm{HbA}_{1 \mathrm{c}}$ in the studied group was $7.6 \%$ at the time when the microcirculation was being examined. Capillaroscopy studies were focused on type 1 diabetic patients and employed non-selective stimuli such as the PORH and VO tests. The relative area covered by capillaries (coverage) was measured before the testing and again after the PORH and $\mathrm{VO}$ tests.

Results: The analysis revealed that none of the skin microcirculation indices correlated significantly with patient age, diabetes duration or metabolic control.

Conclusions: In young patients with uncomplicated type 1 diabetes mellitus skin microcirculation function is not dependent on age, disease duration or metabolic control.

Key words:

diabetes mellitus type 1, skin microcirculation, capillaroscopy, diabetes duration, metabolic control.

\section{Streszczenie}

Wprowadzenie: Mikrokrążenie skóry jest uznawane za odpowiedni model do badania zależności między czynnikami ryzyka sercowonaczyniowego a czynnością mikrokrążenia. Trwa dyskusja, czy badania mikrokrążenia skórnego u młodych pacjentów z cukrzycą typu 1 bez mikroangiopatii mogą być odpowiednie w identyfikacji osób z upośledzoną funkcją śródbłonka.

Cel pracy: Ocena potencjalnych zmian mikrokrążenia skórnego pacjentów w wieku poniżej 18 lat za pomocą kapilaroskopii, testu przekrwienia czynnego (PORH) i okluzji żylnej (VO) oraz ustalenie związku między tymi zmianami a czasem trwania choroby i kontrolą metaboliczną u pacjentów z cukrzycą typu 1.

Materiał i metody: Grupę badaną stanowiło 112 pacjentów pediatrycznych w wieku 8,4-18,0 lat, z medianą 14,95 roku. Mediana

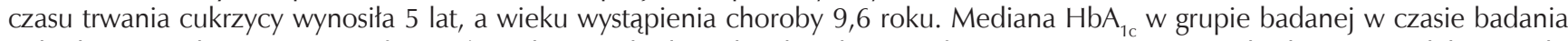
mikrokrążenia skórnego wynosiła 7,6\%. Wykonano badania kapilaroskopowe łącznie z zastosowaniem bodźców nieselektywnych, takich jak testy PORH i VO. Względny obszar pokryty kapilarami (pokrycie) mierzono przed badaniem, po testach PORH i VO.
\end{abstract}


Wyniki: Analiza wykazała, że żaden z parametrów charakteryzujących mikrokrążenie skórne nie korelował istotnie z wiekiem pacjentów, czasem trwania cukrzycy i kontrolą metaboliczną.

Wnioski: U młodych niepowikłanych pacjentów z cukrzycą typu 1 funkcja mikrokrążenia skórnego nie zależy od wieku, czasu trwania choroby i kontroli metabolicznej.

\section{Słowa kluczowe:}

cukrzyca typu 1, mikrokrążenie skórne, kapilaroskopia, czas trwania cukrzycy, kontrola metaboliczna.

\section{Introduction}

Skin microcirculation is recognized as a valid model to study the relationship between cardiovascular risk factors and microvascular function [1]. The impairment of endothelial function in type 1 diabetes leads to typical microvascular complications, such as retinopathy, neuropathy or nephropathy [2]. The impact of diabetes duration on presence of these complications has been described many times [3-8]. Certain studies have also shown that endothelial dysfunction of skin vasculature in type 1 diabetes is associated with the presence of diabetic complications [9-11]. However, it is still a matter of debate whether studying skin microcirculation in young type 1 diabetes mellitus (DM1) patients without existing microangiopathy may be helpful in identifying subjects with impaired endothelial

Table I. Characteristic of study group

\begin{tabular}{ll}
\hline Characteristics & $\begin{array}{l}\text { Diabetic patients } \\
(n=112)\end{array}$ \\
\hline Gender M/F & $51 / 61$ \\
\hline Age [years] & $14.95(8.4 ; 18.00)$ \\
\hline Age at onset of DM [years] & $9.65(1.2 ; 15.20)$ \\
\hline Duration of DM [years] & $5.05(0.3 ; 15.90)$ \\
\hline Insulin dose [units/24 h] & $45(1.5 ; 100)$ \\
\hline Insulin dose [units/kg] & $0.77(0.03 ; 1.36)$ \\
\hline Treatment with pump [\%] & 59.8 \\
\hline HBA ${ }_{10}$ [\%] & $7.6(5.3 ; 13.6)$ \\
\hline Episodes of mild hypoglicaemia & $6(0 ; 30)$ \\
[N/last month] & \\
\hline Episodes of severe hypoglicaemia & $0(0 ; 4)$ \\
[N/last year] & \\
\hline Coexistence of other & 26.8 \\
autoimmunological disease [\%] & \\
\hline
\end{tabular}

Values are presented in mean \pm SD or median (minimum; maximum) DM - diabetes mellitus function. Therefore, investigating the influence of age and diabetes duration on skin microvascular function in children with non-complicated DM1 is of great importance.

One of the recognized methods of skin microcirculation assessment is capillaroscopy [12, 13]. In our previous study on adult DM t.1 patients we used capillaroscopy and L-arginine infusion to assess the skin microcirculation function. For the studies in children we chose capillaroscopy with employment of non-selective stimuli such as post-occlusive reactive hyperemia $(\mathrm{PORH})$ and venous occlusion (VO) tests. Such approach is widely used in microvascular studies of diabetic patients [14-16].

The aim of our study was to evaluate any potential changes in skin microcirculation of patients up to the age of 18 years using capillaroscopy, PORH and VO tests, and to establish the relationship between those changes, disease duration and metabolic control in patients with type 1 diabetes.

\section{Material and methods}

\section{Research design and subjects}

The study group consisted of 112 pediatric patients with type 1 diabetes (51 men and 61 females, with median age 14.95 years; Table I), recruited from the Department of Pediatrics, Diabetology and Endocrinology Medical University of Gdansk. Based on their patients'medical history, physical examination, biochemical analysis none of the study subjects had microangiopathy, including retinopathy, nephropathy and neuropathy according to widely accepted standards [17-19]. All examinations were performed between 8:00 A.M. and 1:00 P.M. The study protocol included medical history, capillaroscopy examination and laboratory testing. In the study group systolic blood pressure was $107 \pm 10.3 \mathrm{~mm} \mathrm{Hg}$, diastolic $60 \pm 6.5 \mathrm{~mm} \mathrm{Hg}$ and heart rate $82 \pm 11$ beats/minute.

The study protocol was approved by the Medical Ethics Committee of the Medical University of Gdansk (NKBBN/277/2014; NKBBN/277-512/2016). Upon entry to the study, each participant gave informed consent (Table I).

All patients followed the same study protocol. After $10 \mathrm{mi}-$ nutes of rest in a sitting position, blood pressure was measured 5 times on both arms. PORH test was performed after additional 20 minutes of rest. VO test followed examination with 5 minutes break.

\section{Skin microcirculation examination}

Subjects participating in the study were asked not to dispatch any skin of their fingernails for least for 2 weeks prior to the 
beginning of the study. During examination, patients remained in a comfortable sitting position with the hand comfortably supported and laid securely under the capillaroscope. The room temperature was controlled by air conditioning and was kept the same during all tests. Body temperature was controlled with the use of a contactless thermometer and was within normal range in all examined patients.

The children were fasting during the microcirculation test. Diabetic patients controlled their blood glucose levels according to daily self-control routine. As previously described, the skin microcirculation was assessed by capillaroscopy [22]. Images were taken using a digital camera (5MPx; OPTA-TECH, Warsaw, Poland) attached to the capillaroscope (OPTA-TECH, CS-CREATIVE SOLUTIONS Group, Warsaw, Poland) and archived on disc. The image analysis allows determination of the ratio between area of the visible capillaries and total area of analyzed image (coverage).

For post occlusive reactive hyperemia test $(\mathrm{PORH})$ the blood pressure cuff was placed around the patient's arm and inflated to a pressure $50 \mathrm{~mm} \mathrm{Hg}$ greater than systolic blood pressure of the patient to completely stop the blood flow for 4 minutes [21]. For venous occlusion test (VO) the blood pressure cuff was inflated to $60 \mathrm{~mm} \mathrm{Hg}$ for 2 minutes. The two above mentioned tests were performed 10 minutes apart.

The following skin microcirculation reactivity parameters were measured: capillary recruitment using PORH - assessed with $\Delta$ coverage $\mathrm{PORH}$ (difference between area covered by capillaries after PORH and at baseline) and the effect of venous occlusion test - $\Delta$ coverage VO (difference between area covered by capillaries after $\mathrm{VO}$ and at baseline).

\section{Statistical analysis}

All the analyses were performed using STATISTICA data analysis software system, version 12. (StatSoft, Inc., Tulsa, OK, USA). Shapiro-Wilk tests were performed to analyze the distribution of continuous variables. Values are expressed as median and range or as mean and standard deviation, as appropriate. Wilcoxon test was used for assessing the significance of changes related to tests. Correlation was assessed by the Spearman's rank correlation test for all continuous variables. The comparison between skin microcirculation parameters, age and diabetes duration was performed using ANOVA test. The $\chi^{2}$ test was used to compare the proportion of genders and the presence of other autoimmunological diseases, frequency of mild and severe hypoglycemia. The level of $p<0.05$ was regarded as statistically significant.

\section{Results}

In Table II the capillaroscopy data obtained at baseline, during $\mathrm{PORH}$ and during venous occlusion are presented. The comparison of the coverage at baseline and during both the $\mathrm{PORH}$ and $\mathrm{VO}$ tests for the whole study group differed significantly $(p<0.001)$. The values of skin microcirculation parameters such as coverage at baseline, after $\mathrm{PORH}$ and after VO
Table II. Skin capillaroscopy data

\begin{tabular}{ll}
\hline Characteristics & $\begin{array}{l}\text { Diabetic patients } \\
(n=112)\end{array}$ \\
\hline COVERAGE [\%] & $17.29 \pm 2.4$ \\
\hline [1] BASELINE & $16.62 \pm 2.92$ \\
\hline $\begin{array}{l}\text { [2] After Post-Oclusive Reactive } \\
\text { Hyperemia (PORH) }\end{array}$ & $16.56 \pm 2.88$ \\
\hline [3] After Venous Occlusion (VO) & $\#-0.67 \pm 2.5$ \\
\hline ABSOLUTE CHANGE IN COVERAGE [\%] \\
\hline$\Delta$ PORH [2]-[1] & $\#-0.73 \pm 2.17$ \\
\hline$\Delta$ VO [3]-[1] & $-3.42 \pm 14.15$ \\
\hline$\Delta \mathrm{PORH}([2]-[1]) /[1]$ & $-3.83(-39.8 ; 44.78)$ \\
\hline$\Delta \mathrm{VO}([3]-[1]) /[1]$ &
\end{tabular}

$p$ for comparison with condition before PORH or VO: $\# p<0.001$; Values represented in means \pm SD or median (minimum; maximum) COVERAGE - the ratio between area of the visible capillaries and total area of analyzed image

averaged for one year intervals were obtained. The analysis revealed no significant differences between age groups for the following variables: coverage at baseline $(p=0.98)$, coverage after PORH $(p=0.66)$ and coverage after VO $(p=0.75)$. The patient subgroups distinguished by patients' age differed significantly in the duration of diabetes. Therefore, in subsequent analyzes, we compared the parameters describing skin microcirculation age groups depending on the basis of their median diabetes duration.

There was no significant difference between the analyzed age groups with regards to diabetes duration for the following variables: coverage at baseline (Figure 1), coverage after $\mathrm{PORH}$ and coverage after $\mathrm{VO}$. The respective statistics and significance level for age group comparison are: for coverage after PORH $(p=0.57)$ and for coverage after VO $(p=0.71)$. Evaluation of the relationship between skin microcirculation parameters- coverage, age and metabolic control shows that the patient age, the onset of diabetes and diabetes duration did not correlate significantly with skin microcirculation parameters such as coverage at baseline, coverage after $\mathrm{PORH}$ coverage after $\mathrm{VO}$ or $\Delta$ coverage $\mathrm{PORH}$ and $\Delta$ coverage $\mathrm{VO}$. In addition, $\mathrm{HbA} 1 \mathrm{c}$ level, insulin dose/kg, numbers of mild or heavy episodes of hypoglycemia did not correlate significantly with skin microcirculation parameters. No differences were found between values describing skin microcirculation when the groups were divided by sex, type of treatment (pump or pens) or coexistence of other autoimmunological diseases. 


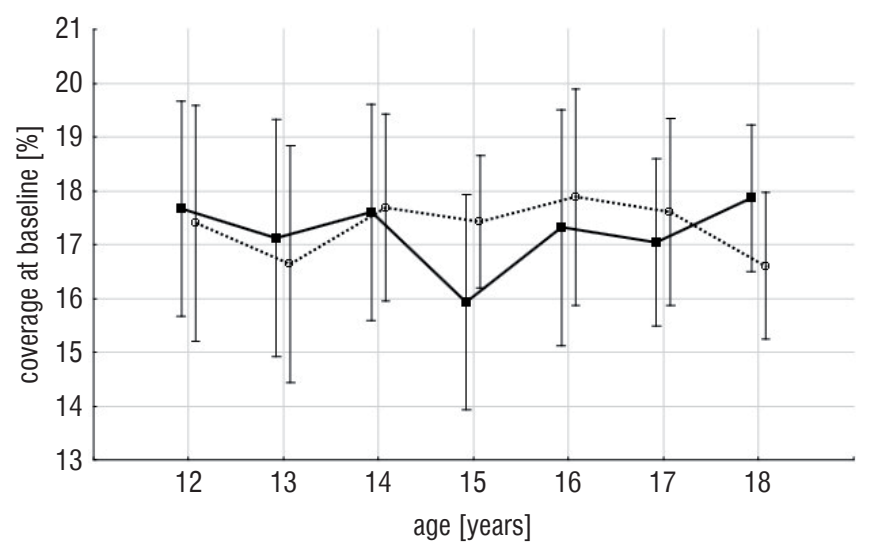

diabetes duration below median

O diabetes duration above median

Figure 1. Comparison of coverage at baseline in age groups depending on the diabetes duration. Data is presented as mean $\pm 0,95 \mathrm{Cl}$

\section{Discussion}

Our previous study has shown that adults with diabetes onset before 19.7 years of age have better skin microcirculation function than those with later onset of disease. Moreover, in studied subjects we found no correlation between skin microcirculation parameters and diabetes duration [22]. In this adult diabetic group study we have used capillaroscopy combined with I-arginine infusion to assess skin microcirculation reactivity [22]. Unlike I-arginine, $\mathrm{PORH}$ is a completely non-invasive test. That is why it was chosen for testing in pediatric patients.

The present analysis based on data collected on 112 children with non-complicated diabetes type 1 aged 8-18 years showed that studied skin microcirculation parameters are independent of patient age and diabetes duration. Our data are in line with the results of a study by Ladeia et al. [23]. Based on the analysis of the endothelial function using PORH test and flow mediated dilatation in diabetic children aged from 7 to 18 years with diabetes duration below 5 years, Ladeia et al. concluded that endothelial function was not altered in these patients. The report of Tibrica also showed no significant correlation between the skin capillary function and diabetes duration in adults with non-complicated diabetes type 1 patients aged $27.1 \pm 10.6$ years with disease duration of $10(1 ; 45)$ years [15].

Contrasting results were found by Jörneskog's and et al. in their study on 20 adult diabetes type 1 patients, including both subjects with (age of $46.1 \pm 9.8$, diabetes duration 17.7 \pm 9.6 years) and without complications (age $29.9 \pm 7.0$, diabetes duration $4.8 \pm 2.9$ years). They concluded that the re- duction in maximal blood flow in skin capillaries was more pronounced in patients with diabetic complications. According to cited authors, changes in capillary flow could suggest that skin microcirculation dysfunction precedes late diabetic complications [14]. The same conclusion was presented by Khan et al. who studied the endothelium-dependent responses in relation to diabetes duration using iontophoresis and laser Doppler flowmetry [24]. However, it is important to note the limitations of some of these reports, such as the relatively small size of the groups studied as well as the considerable progress that has been made in diagnosis as well as the prophylactic standards and insulinotherapy in diabetes type 1 over the past 20 years. The reports on age related reduction of skin capillary density were already described by several authors $[25,26]$. The researchers observed significant reduction of dermal papillary loops in elderly skin when compared with young skin. Tibirica had found a positive correlation between functional and structural capillary densities with age in 59 adults with type 1 diabetes [15]. Piotto et al. found a significant increase in capillary density with age in a group of 100 healthy subjects aged 5 to 18 years [27]. However, the analysis of our data showed no correlation between skin microcirculation parameters and age of examined children. Additionally, these parameters did not correlate with metabolic status described by the level of glycated hemoglobin, type of treatment and the number of hypoglycemic episodes. The published studies on the relationship between skin microvascular parameters and metabolic control $[15,22]$ in adult patients with type 1 diabetes are not consistent. Some of them demonstrated that skin microcirculation reactivity was independent of the metabolic state described by $\mathrm{HbA} 1 \mathrm{c}$ level $[15,22]$. On the other hand, Jorneskog et al. reported significant differences in capillary flow between 20 patients with non-complicated disease with bad and good metabolic control rather than diabetes duration [16]. Schlager and coworkers carried out a study on 896 children and adolescents (4.3-18.1 years) to investigate the impact of age and gender on microcirculatory function during adolescence assessed by postocclusive reactive hyperaemia (PORH) and laser Doppler fluxmetry. They showed the impact of gender on microvascular reactivity in adolescents but not at younger ages [28]. Our present study not disclose gender related differences in skin microcirculation parameters assessed by PORH and capillaroscopy. Those findings we have already observed in adults with type 1 diabetes mellitus [22] when we used L-arginine infusion and capillaroscopy.

In the current study we did not examine children younger than 8 years old because of the need for patient cooperation during the time of examination. Our analysis was aimed to find first signs of age dependent changes in microcirculation. For this analysis we have only included children without retinopathy, nephropathy and neuropathy. The lack of control group should not be recognized as a limitation of our study, as we intended to analyze the age-related changes in structure and function of skin microcirculation in diabetic patients in relation to diabetes duration. 


\section{Conclusions}

The final conclusion from our study is that skin microcirculation function is not associated with age, disease duration and metabolic control in pediatric patients with uncomplicated type 1 diabetes mellitus.

\section{References}

1. Jzerman RG, de Jongh RT, Beijk MA, et al. Individuals at increased coronary heart disease risk are characterized by an impaired microvascular function in skin. Eur J Clin Invest 2003; 33: 536-542. doi: 10.1046/j.1365-2362.2003.01179.x

2. Hurks R, Eisinger MJ, Goovaerts I, et al. Early endothelial dysfunction in Young type 1 diabetics. Eur J Vasc Endovasc Surg 2009; 37 611-615. doi: https://doi.org/10.1016/j.ejvs.2009.01.015

3. Donaghue KC, Fairchild JM, Craig ME, et al. Do all prepubertal years of diabetes duration contribute equally to diabetes complications? Diabetes complication screening in 937 children and adolescents. Diabetes Care 2003; 26: 1224-1229.

4. Donaghue KC, Fung AT, Hing S, et al. The effect of prepubertal diabetes duration on diabetes: microvascular complications in early and late adolescence. Diabetes Care 1997; 20: 77-80.

5. McNally PG, Raymond NT, Swift PG, et al. Does the prepubertal duration of diabetes influence the onset of microvascular complications? Diabet Med 1993; 10: 906-908. doi: 10.1111/j.14645491.1993.tb00005.x

6. Burger W, Hovener G, Dusterhus R, et al. Prevalence and development of retinopathy in children and adolescents with type 1 (insulin-dependent) diabetes mellitus: a longitudinal study. Diabetologia 1986; 29: 17-22. doi: 10.1007/bf02427275

7. Holl RW, Lang GE, Grabert M, et al. Diabetic retinopathy in pediatric patients with type-1 diabetes: effect of diabetes duration, prepubertal and pubertal onset of diabetes, and metabolic control. J Pediatr 1998; 132: 790-794. doi: 10.1016/s0022-3476(98)70305-1

8. Holl RW, Grabert M, Thon A, Heinze E. Urinary excretion of albumin in adolescents with type 1 diabetes. Diabetes Care 1999; 22 1555-1560. doi: 10.2337/diacare.22.9.1555

9. Chang $\mathrm{CH}$, Tsai RK, Wu WC, et al. Use of dynamic capillaroscopy for studying cutaneous microcirculation in patients with diabetes mellitus. Microvasc Res 1997; 53: 121-127. doi: 10.1006/mvre.1996.2003

10. Nguyen TT, Shaw JE, Robinson C, et al. Diabetic retinopathy is related to both endothelium-dependent and -independent responses of skin microvascular flow. Diabetes Care 2011; 34: 1389-1393. doi: 10.2337/dc10-1985

11. Quattrini C, Harris ND, Malik RA, Tesfaye S. Impaired skin microvascular reactivity in painful diabetic neuropathy. Diabetes Care 2007; 30: 655-659. doi: 10.2337/dc06-2154

12. Grassi W, Del Medico P. Atlas of capillaroscopy. EDRA, Milano 2004.

13. Grassi W, De Angelis R. Capillaroscopy: questions and answers. Clin Rheumatol 2007; 26: 2009-2016. doi: 10.1007/s10067-007-0681-3

14. Jörneskog G, Brismar K, Fagrell B. Skin capillary circulation severely impaired in toes of patients with IDDM. with and without late diabetic complications. Diabetologia 1995; 38: 474-480. 10.1007/bf00410286

\section{Acknowledgement}

This study was supported by the State Committee for Scientific Research ST-120 and ST 02-0559/07/136 (Medical University of Gdańsk, Poland).

15. Tibiriça E, Rodrigues E, Cobas RA, Gomes MB. Endothelial function in patients with type 1 diabetes evaluated by skin capillary recruitment. Microvasc Res 2007; 73: 107-112. doi: 10.1016/j.mvr.2006.11.004

16. Jörneskog G, Brismar K, Fagrell B. Pronounced skin capillary ischemia in the feet of diabetic patients with bad metabolic control. Diabetologia 1998; 41: 410-415. doi: 10.1007/s001250050923

17. American Diabetes Association. Microvascular complications and foot care. Sec. 9. In Standards of Medical Care in Diabetes 2016. Diabetes Care 2016; 39 (Suppl. 1)

18. Singer DE, Schachat A, Nathan DM, et al. Screening guidelines for diabetic retinopathy. American College of Physicians. American Diabetes Association. and American Academy of Ophthalmology. Ann Intern Med 1992; 116: 683-685. doi: 10.7326/0003-4819-116-8-660

19. Dyck PJ. Detection. characterization. and staging of polyneuropathy: assessed in diabetics. Muscle Nerve 1988; 11: 21-32. doi: 10.2337/dc08-1805

20. Kozera GM, Wolnik B, Kunicka KB, et al. Cerebrovascular reactivity. intima-media thickness. and nephropathy presence in patients with type 1 diabetes. Diabetes Care 2009; 32: 878-882. doi: 10.2337/ dc08-1805

21. Cracowski JL, Minson CT, Salvat-Melis M, Halliwill JR. Methodological issues in the assessment of skin microvascular endothelial function in humans. Trends Pharmacol Sci 2006; 27: 503-508. doi 10.1016/j.tips.2006.07.008

22. Neubauer-Geryk J, Kozera GM, Wolnik B, et al. Decreased reactivity of skin microcirculation in response to L-arginine in later-onset type 1 diabetes. Diabetes Care 2013; 36: 950-956. doi: 10.2337/dc12-0320

23. Ladeia AM, Ladeia-Frota C, Pinho L, et al. Endothelial dysfunction is correlated with microalbuminuria in children with short-duration type 1 diabetes. Diabetes Care 2005; 28: 2048-2050. doi: 10.2337/ diacare.28.8.2048

24. Khan F, Elhadd TA, Greene SA, Belch JJ. Impaired skin microvascular function in children. adolescents. and young adults with type 1 diabetes. Diabetes Care 2000; 23: 215-220. doi: 10.2337/ diacare.23.2.215

25. Hern S, Mortimer PS. Visualization of dermal blood vessels-capillaroscopy. Clin Exp Dermatol 1999; 24: 473-478. doi: 10.1046/j.13652230.1999.00537.x

26. Kelly RI, Pearse R, Bull RH, et al. The effects of aging on the cutaneous microvasculature. J Am Acad Dermatol 1995; 33: 749-756. doi: 10.1016/0190-9622(95)91812-4

27. Piotto DP, Sekiyama J, Kayser C, et al. Nailfold videocapillaroscopy in healthy children and adolescents: description of normal patterns. Clin Exp Rheumatol 2016; 34 Suppl 100: 193-199.

28. Schlager O, Giurgea A, Hammer A, et al. Impact of age and gender on microvascular function. Eur J Clin Invest 2014; 44: 766-774. doi: 10.1111/eci.12293 